\title{
Study of Mortality Pattern in an Organized Farming Sector amongst Kashmir Merino Sheep
}

\author{
Imran Bashir*, Mubashir Ali Rather, Jan Mohammad Rather, Ishfaq Ahmad Hajam, \\ Javaid Ahmad Baba, Mohammad Maroof Shah and Zahoor Ul Haq
}

\author{
Sheep Husbandry Department, Kashmir, India
}

*Corresponding author

Keywords

Age group,

Disease, Infectious,

Mortality,

Non-infectious,

Season, Sheep

Article Info

Accepted:

12 March 2020

Available Online:

10 April 2020

\begin{abstract}
A B S T R A C T
While it is not possible to save every single lamb, but there is huge scope to reduce mortality percentage for economic sheep production through development of sheep flock health programs. These flock health programs require information on diseases and their predisposing factors causing mortality and thus huge economic losses. Therefore, this information pertaining to losses through deaths need to be in form of profile indicating importance of disease and predisposing factors in terms of susceptible age group, seasonal incidence of the disease and the annual variation in its occurrence. Hence an investigation of overall mortality to identify predisposing factors at Sheep Breeding Farm, Kralpathri was carried out from 2013 to 2020 with accurate data recording for lambing and mortality. Total of 7733 animals were studied. Among them 2385 male and 5348 females were studied. Overall mortality recorded was 823 (10.64\%). Among them were 387 (16.23\%) males and $436(8.15 \%)$ females. High mortality was observed upto 1 year age i.e. 592 (29.39) than after 1 year age i.e. 231 (4.03). Majority of deaths occurred due to infectious diseases $(625,8.08 \%)$. Non infectious diseases contributed to $198(2.56 \%)$ deaths. Among infectious diseases, pneumonia (164, $19.93 \%)$ and Gastro-enteritis $(159,19.32 \%)$ and among non-infectious diseases, hypothermia $(108,13.12 \%)$ and wild attack $(47,5.71 \%)$ were major contributors of mortality in the present investigation. The incidence of Gid was $8.51 \%$ (70 cases). Highest mortality was observed in spring (40.80\%)and winter $(24.67 \%)$. By adopting proper hygiene and basic managemental practices the mortality can be reduced to a large extent.
\end{abstract}

\section{Introduction}

The efficient and economic sheep production mainly depends on daily weight gain and ewe reproduction performance i.e. conception rate and litter size. Therefore, conception rate and litter size are important traits in commercial sheep enterprise. However, profitability mainly depends on number of lambs sold per ewe. The sheep mortality is a drag on litter size and number of lambs sold per ewe. Further, it is not possible to save each and every lamb born. However, it is possible to decrease lamb mortality and increase lamb marketing significantly by establishing facts relating to cause and time of morality. Establishing cause and identifying when mortality takes place (age, season, month 
etc.,) form basis for reducing it in subsequent years. Therefore, present investigation was under taken to identify the possible cause at the farm to reduce it in future.

\section{Materials and Methods}

A retrospective and prospective study was conducted on mortality from 2013-2020 at Government Sheep Breeding Farm Kralpathri Kashmir. The farm was located at $33^{\circ}$ 53' latitude $\mathrm{N}$ and $74^{\circ} 37^{\prime}$ longitude $\mathrm{E}$, in heart of district Budgam about 45 kilometers from Srinagar. The topography of the farm is undulating hills covered by forest land spread over a vast area. The farm was established in the sixties for up-gradation of non-descript sheep population of Kashmir valley. The sheep are stall-fed during winter for five months from fifteen November to 15 April only. The fodder is fed to animals @ $1.5 \mathrm{~kg}$, $1.6 \mathrm{~kg}$ and $1.6 \mathrm{~kg}$ per day per adult ewe, ram and hogget, respectively. The concentrate ration is fed @600gms/day/adult male and @ 500gms /day/ewe and @ 300gms /sheep having age under one year. The sheep are fed pelleted feed, maize, wheat bran, oil cakes, jaggery and mineral mixture. Sheep are not provided any feed and fodder from first April to $15^{\text {th }}$ November except during draught periods. However, the common salt @ $10 \mathrm{gms} / \mathrm{head} /$ week is given to these animals.

The sheep were vaccinated against bacterial and viral diseases, like enterotoxaemia and sheep pox as per schedule. The endoparisitic \& ectoparisitic control measures were also followed using recommended drugs. Dipping was practiced twice a year. Veterinary aid was provided as and when needed. Cleanliness of sheds and hygienic measures was regularly done. The animals were treated for any disease by expert veterinarians after proper diagnosis. Ewes were mated in the late summer and early autumn after flushing and screening for Brucellosis. The ewes having body weight less than $30 \mathrm{~kg}$ were abstained from breeding. The ewes were divided into groups of about 100 sheep, based on body weight and wool yield traits. Same criteria were followed for selection of Rams. However, due care was taken to avoid close inbreeding. The lambing commenced in January and terminated at the end of March. Lambs were weaned at an age of 4-5 months. The male and female weaners were reared in together. The data obtained were analyzed on $\%$ age basis. The deaths were grouped according to the causes of death into infectious and non-infectious causes, year (seven groups), sex (two groups), month (12 groups), age (5 groups i.e 0-30 days, 1-5 months, >5-12 months, 1-2 years and above two years).

\section{Results and Discussion}

Overall mortality of $10.64 \%$ was observed in the present study. The mortality was higher among males $(16.23 \%)$ than females $(8.15 \%)$ females. Similarly, higher mortality was observed in age group of 0 days to 1 year age group (29.39\%) than above 1 year age groups $(4.03 \%)$ and higher mortality was caused by infectious diseases $(8.08 \%)$ than noninfectious diseases $(2.56 \%)$ (Table 1). Makhdoomi and Tufani (2010) reported overall mortality of $9.77 \%$ in Kashmir Merino sheep with more death due to infectious diseases $(7.55 \%)$ than noninfectious diseases $(2.23 \%)$. MukasaMugerwa et al., (2000) in indigenous Horro and Menze sheep, Sawalha et al., (2007) in Scottish Blackface sheep, Mandal et al., (2007) in Muzaffarnagari sheep, Sarkar et al., (2008) in crossbred and exotic sheep and Vatankhah and Talebi (2009) in LoriBakhtiari lambs also reported higher mortality in male sheep than females. The mortality percentage varied between years and may be attributed to difference in management and environmental variations caused by variation 
in ambient temperature, rain fall etc. Among the infectious diseases, pneumonia, Gastroenteritis and Hemorrhagic enteritis were the major ones that contributed $19.93 \%, 19.32 \%$ and $9.48 \%$ deaths, respectively. Similarly, among non-infectious Hypothermia and Wild attack were major ones that contributed, respectively $13.12 \%$ and $5.71 \%$ (Table 2). Makhdoomi and Tufani (2010) also reported pneumonia and enteritis as major contributors among infectious diseases. However, among non-infectious grass poisoning, urolithiasis and hypothermia were reported as major contributors of mortality by Makhdoomi and Tufani (2010). Maru et al., (1993) also reported pneumonia as major cause of mortality in a sheep flock.

Mortality rates tend to increase at extremely low or extremely high birth weights (Mendel et al., 1989; Notter and Copenhaver, 1980). Also, it has been reported that higher litter sizes have reduced birth weight and hence the survival of lambs (Turkson and Sualisu, 2005). Results of the present study partially support those findings, since the highest and the lowest birth weights and relatively high perinatal mortality were found. As sheep production is directly influenced by the number of lambs born and reared from a flock at any given time, it is highly important to identify the cause of lamb loss and to take appropriate measures to reduce it. Apart from low birth weight, causes of early lamb losses could be stress, injuries, organ malfunction, starvation or mis-mothering. Some of these causes are closely connected to the season, since during different times of the year; sheep (and the newly born) are exposed to different environmental circumstances with regard to humidity and temperature. Therefore, for proper lambing management the season should be taken into consideration since it has great impact on birth weight and perinatal lamb mortality. The animal should be born in enjoinment which is clean, dry, sheltered and conducive for the animals to get up after birth, suck the dam and establish bonding with the dam. No conventional area can be sterilized but it can be reasonably made clean to minimize the infection.

The mortality (\%) of was $24.67,40.83,17.23$ and 17.23was observed during winter, spring, summer and autumn seasons, respectively. Highest mortality was observed in spring and may be attributed to more lamb deaths at younger age. Highest mortality in spring was also reported by Makhdoomi and Tufani (2010) at sheep Breeding Farm Dachigam. Higher number of deaths due to hypothermia, infectious diseases of GIT and Respiratory tract and were observed during spring and autumn seasons could be due to supply unhygienic ice cold water supply for livestock and prevailing management conditions during these seasons. Among different months of the year, highest mortality was observed in April i.e. 16 cases and lowest mortality was observed in September. The lambing seasons commenced in January and terminated at the end of March.

Perinatal lamb deaths, which occur around parturition time, result in significant lamb losses. The extent of perinatal mortality depends mostly on the management system, but the major factors affecting lamb survival include age of lamb, litter size, birth weight, nutrition and parity of the ewe and season of birth (Gatenby et al., 1997; Ambruster et al., 1991; Notter et al., 1991). Ingestion of colostrum by new born immediately after birth is very important as lambs don't receive placental immunity during fetal life. Colostrum, which is a rich source of immunoglobulin, helps in passage of first feces (meconium). First few weeks are very critical in lamb's life and lamb should consume enough colostrum during this time. Herd density is an important factor determining the propagation of disease (Table 3 ). 
Table.1 Incidence of lamb mortality (\%) in Kralpathri sheep breeding farm during the period 2013 to 2020

\begin{tabular}{|c|c|c|c|c|c|c|c|c|c|c|c|c|}
\hline \multirow{3}{*}{ Year } & \multirow{3}{*}{$\begin{array}{c}\text { Overall } \\
\text { flock } \\
\text { size }\end{array}$} & \multirow{2}{*}{\multicolumn{2}{|c|}{$\begin{array}{c}\text { Adults }>1 \\
\text { year age }\end{array}$}} & \multirow{2}{*}{\multicolumn{2}{|c|}{$\begin{array}{c}\text { Lambs } 0 \\
\text { days-1 year } \\
\text { age }\end{array}$}} & \multirow{3}{*}{$\begin{array}{l}\text { Overall } \\
\text { Mortality } \\
(\%)\end{array}$} & \multirow{3}{*}{$\begin{array}{c}\text { Mortality } \\
\text { in females } \\
(\%)\end{array}$} & \multirow{3}{*}{$\begin{array}{l}\text { Mortality } \\
\text { in males } \\
(\%)\end{array}$} & \multirow{3}{*}{$\begin{array}{c}\text { Mortality } \\
\text { in Adults } \\
>1 \text { year } \\
\text { age }(\%)\end{array}$} & \multirow{3}{*}{$\begin{array}{c}\text { Mortality } \\
\text { in Lambs } \\
0 \text { days-1 } \\
\text { year age } \\
(\%)\end{array}$} & \multirow{3}{*}{$\begin{array}{l}\text { Mortality } \\
\text { due to } \\
\text { infectious } \\
\text { diseases } \\
(\%)\end{array}$} & \multirow{3}{*}{$\begin{array}{c}\text { Mortality } \\
\text { due to non- } \\
\text { infectious } \\
\text { diseases }(\%)\end{array}$} \\
\hline & & & & & & & & & & & & \\
\hline & & Male & Female & Male & Female & & & & & & & \\
\hline $\begin{array}{c}2013- \\
14\end{array}$ & 1332 & 200 & 768 & 189 & 175 & $\begin{array}{c}156 \\
(11.71)\end{array}$ & $87(9.23)$ & $\begin{array}{c}69 \\
(17.74)\end{array}$ & $54(5.58)$ & $\begin{array}{c}102 \\
(28.02)\end{array}$ & $\begin{array}{c}108 \\
(8.11)\end{array}$ & $48(3.60)$ \\
\hline $\begin{array}{l}2014- \\
15\end{array}$ & 1422 & 292 & 861 & 131 & 138 & $\begin{array}{c}174 \\
(12.24)\end{array}$ & $82(8.21)$ & $\begin{array}{c}92 \\
(21.75)\end{array}$ & $35(3.04)$ & $\begin{array}{c}139 \\
(51.67)\end{array}$ & $\begin{array}{l}124( \\
8.72)\end{array}$ & $50(3.52)$ \\
\hline $\begin{array}{c}2015- \\
16\end{array}$ & 1110 & 145 & 566 & 184 & 215 & $\begin{array}{c}139 \\
(12.52)\end{array}$ & $\begin{array}{c}89 \\
(11.40)\end{array}$ & $\begin{array}{c}50 \\
(15.20)\end{array}$ & $46(6.47)$ & $93(23.31)$ & $\begin{array}{c}112 \\
(10.09)\end{array}$ & $27(2.43)$ \\
\hline $\begin{array}{c}2016- \\
17\end{array}$ & 931 & 163 & 508 & 136 & 124 & $71(7.63)$ & $31(4.91)$ & $\begin{array}{c}40 \\
(13.38)\end{array}$ & $23(3.43)$ & $\begin{array}{c}48 \\
(18.46)\end{array}$ & $59(6.34)$ & $12(1.29)$ \\
\hline $\begin{array}{c}2017- \\
18\end{array}$ & 1088 & 255 & 603 & 111 & 119 & $81(7.44)$ & $45(6.23)$ & $36(9.84)$ & $31(3.61)$ & $\begin{array}{c}50 \\
(21.73)\end{array}$ & $66(6.07)$ & $15(1.38)$ \\
\hline $\begin{array}{c}2018- \\
19\end{array}$ & 893 & 177 & 466 & 123 & 127 & 80 (8.96) & 45 (7.59) & $\begin{array}{c}35 \\
(11.67)\end{array}$ & $18(2.80)$ & $\begin{array}{c}62 \\
(24.80)\end{array}$ & $62(6.94)$ & $18(2.02)$ \\
\hline $\begin{array}{c}2019- \\
20\end{array}$ & 957 & 158 & 557 & 121 & 121 & $\begin{array}{c}122 \\
(12.75)\end{array}$ & $57(8.41)$ & $\begin{array}{c}65 \\
(23.30)\end{array}$ & $24(3.36)$ & $\begin{array}{c}98 \\
(40.50)\end{array}$ & $94(9.82)$ & $28(2.93)$ \\
\hline Overall & 7733 & 1390 & 4329 & 995 & 1019 & $\begin{array}{c}823 \\
(10.64)\end{array}$ & $\begin{array}{c}436 \\
(8.15)\end{array}$ & $\begin{array}{c}387 \\
(16.23)\end{array}$ & $\begin{array}{c}231 \\
(4.03)\end{array}$ & $\begin{array}{c}592 \\
(29.39)\end{array}$ & $\begin{array}{c}625 \\
(8.08)\end{array}$ & $198(2.56)$ \\
\hline
\end{tabular}


Table.2 Incidence of mortality due to various infectious and non-infectious diseases in Kashmir Merino sheep during 2013 to 2020

\begin{tabular}{|c|c|c|c|c|c|c|c|c|c|}
\hline & 2013-14 & 2014-5 & 2015-16 & 2016-17 & 2017-18 & 2018-19 & 2019-20 & No of deaths & $\%$ \\
\hline Pneumonia & 36 & 29 & 28 & 21 & 17 & 11 & 22 & 164 & 19.93 \\
\hline Gastro-Enteritis & 25 & 35 & 27 & 22 & 9 & 20 & 21 & 159 & 19.32 \\
\hline Hypothermia & 16 & 25 & 19 & 12 & 10 & 12 & 14 & 108 & 13.12 \\
\hline Hemorrhagic enteritis & 14 & 17 & 12 & 10 & 9 & 7 & 9 & 78 & 9.48 \\
\hline Gid & 24 & 10 & 7 & 9 & 11 & 6 & 3 & 70 & 8.51 \\
\hline Wild attack & 9 & 14 & 10 & 3 & 6 & 1 & 4 & 47 & 5.71 \\
\hline Hemorrhagic gastro enteritis & 2 & 9 & 8 & 5 & 3 & 7 & 4 & 38 & 4.62 \\
\hline Enteritis & 7 & 3 & 6 & 3 & 5 & 2 & 5 & 31 & 3.76 \\
\hline Liver cirrhosis & 5 & 3 & 7 & 3 & 1 & 4 & 3 & 26 & 3.16 \\
\hline Lung abscess & 1 & 4 & 4 & 3 & 2 & 1 & 3 & 18 & 2.19 \\
\hline Septicemia & 1 & 7 & 0 & 0 & 0 & 4 & 2 & 14 & 1.70 \\
\hline Liver abscess & 1 & 2 & 2 & 1 & 1 & 3 & 2 & 12 & 1.46 \\
\hline Sheep pox & 3 & 2 & 2 & 3 & 1 & 0 & 0 & 11 & 1.34 \\
\hline Nephrites & 4 & 2 & 2 & 1 & 1 & 0 & 0 & 10 & 1.22 \\
\hline Bloat & 1 & 4 & 0 & 0 & 1 & 0 & 0 & 6 & 0.73 \\
\hline Ecthyma & 0 & 2 & 2 & 1 & 0 & 0 & 0 & 5 & 0.61 \\
\hline Abomasitis & 0 & 2 & 0 & 0 & 0 & 0 & 1 & 3 & 0.36 \\
\hline Aortic Rupture & 1 & 1 & 0 & 0 & 1 & 0 & 0 & 3 & 0.36 \\
\hline Drowning & 0 & 0 & 1 & 0 & 1 & 0 & 0 & 2 & 0.24 \\
\hline Poisoning & 0 & 1 & 1 & 0 & 0 & 0 & 1 & 3 & 0.36 \\
\hline Hepatitis & 1 & 1 & 0 & 0 & 0 & 0 & 0 & 2 & 0.24 \\
\hline Hydatidosis & 1 & 0 & 0 & 0 & 0 & 1 & 0 & 2 & 0.24 \\
\hline Ascites & 0 & 0 & 0 & 0 & 1 & 0 & 0 & 1 & 0.12 \\
\hline Coccidiosis & 0 & 1 & 0 & 0 & 0 & 0 & 0 & 1 & 0.12 \\
\hline Encephalitis & 0 & 0 & 0 & 1 & 0 & 0 & 0 & 1 & 0.12 \\
\hline Enterotoxaemia & 1 & 0 & 0 & 0 & 0 & 1 & 0 & 2 & 0.24 \\
\hline Fluke Infestation & 1 & 0 & 0 & 0 & 0 & 0 & 0 & 1 & 0.12 \\
\hline Gastritis & 0 & 0 & 1 & 0 & 0 & 0 & 0 & 1 & 0.12 \\
\hline Metiritis & 1 & 0 & 0 & 0 & 0 & 0 & 0 & 1 & 0.12 \\
\hline Omasal impaction & 0 & 0 & 0 & 0 & 0 & 0 & 1 & 1 & 0.12 \\
\hline Peritonitis & 1 & 0 & 0 & 0 & 0 & 0 & 0 & 1 & 0.12 \\
\hline UB Rupture & 0 & 0 & 0 & 0 & 1 & 0 & 0 & 1 & 0.12 \\
\hline
\end{tabular}

\%age=Mortality with respect to total mortalities (823) 
Table.3 Effect of climatic conditions on lamb mortality in Kashmir Merino sheep due to various infectious and Non-infectious diseases during 2013 -20

\begin{tabular}{|c|c|c|c|c|c|c|c|c|c|c|c|c|}
\hline & January & February & March & April & May & June & July & August & September & October & November & December \\
\hline Abomasitis & 0 & 0 & 0 & 0 & 3 & 0 & 0 & 0 & 0 & 0 & 0 & 0 \\
\hline Aortic Rupture & 0 & 0 & 0 & 0 & 1 & 2 & 0 & 0 & 0 & 0 & 0 & 0 \\
\hline Ascites & 0 & 0 & 0 & 0 & 0 & 0 & 0 & 0 & 0 & 1 & 0 & 0 \\
\hline Bloat & 0 & 0 & 0 & 2 & 0 & 1 & 0 & 1 & 0 & 1 & 1 & 0 \\
\hline Coccidiosis & 0 & 0 & 0 & 0 & 0 & 0 & 1 & 0 & 0 & 0 & 0 & 0 \\
\hline Drowning & 0 & 0 & 0 & 0 & 1 & 0 & 1 & 0 & 0 & 0 & 0 & 0 \\
\hline Ecthyma & 0 & 0 & 0 & 5 & 0 & 0 & 0 & 0 & 0 & 0 & 0 & 0 \\
\hline Encephalitis & 0 & 0 & 0 & 0 & 0 & 0 & 0 & 0 & 1 & 0 & 0 & 0 \\
\hline Enteritis & 0 & 0 & 2 & 6 & 2 & 12 & 3 & 1 & 0 & 4 & 1 & 0 \\
\hline Enterotoxaemia & 0 & 0 & 0 & 1 & 1 & 0 & 0 & 0 & 0 & 0 & 0 & 0 \\
\hline Fluke Infestation & 0 & 0 & 0 & 0 & 0 & 1 & 0 & 0 & 0 & 0 & 0 & 0 \\
\hline Gastritis & 0 & 0 & 0 & 1 & 0 & 0 & 0 & 0 & 0 & 0 & 0 & 0 \\
\hline Gastro Enteritis & 9 & 12 & 24 & 23 & 23 & 14 & 2 & 9 & 8 & 9 & 19 & 8 \\
\hline Gid & 16 & 7 & 4 & 5 & 6 & 1 & 0 & 1 & 4 & 7 & 8 & 11 \\
\hline Poisoning & 0 & 0 & 0 & 0 & 2 & 1 & 0 & 0 & 0 & 0 & 0 & 0 \\
\hline Haemorrhagic enteritis & 1 & 4 & 5 & 16 & 17 & 13 & 5 & 2 & 4 & 3 & 5 & 3 \\
\hline $\begin{array}{c}\text { Haemorrhagic gastro } \\
\text { enteritis }\end{array}$ & 2 & 3 & 7 & 18 & 2 & 0 & 1 & 0 & 0 & 5 & 0 & 0 \\
\hline Hepatitis & 1 & 0 & 1 & 0 & 0 & 0 & 0 & 0 & 0 & 0 & 0 & 0 \\
\hline Hydatidosis & 0 & 0 & 0 & 1 & 0 & 1 & 0 & 0 & 0 & 0 & 0 & 0 \\
\hline Hypothermia & 5 & 6 & 32 & 25 & 8 & 10 & 17 & 4 & 0 & 0 & 0 & 1 \\
\hline Liver abscess & 1 & 1 & 1 & 1 & 1 & 1 & 1 & 1 & 1 & 0 & 3 & 0 \\
\hline Liver cirrhosis & 3 & 5 & 3 & 4 & 2 & 1 & 0 & 3 & 1 & 1 & 2 & 1 \\
\hline Lung abscess & 0 & 0 & 4 & 5 & 3 & 1 & 0 & 1 & 0 & 0 & 2 & 2 \\
\hline Metritis & 1 & 0 & 0 & 0 & 0 & 0 & 0 & 0 & 0 & 0 & 0 & 0 \\
\hline Nephrites & 1 & 0 & 0 & 2 & 2 & 2 & 0 & 0 & 0 & 1 & 2 & 0 \\
\hline Omasal impaction & 0 & 0 & 0 & 0 & 0 & 0 & 0 & 0 & 0 & 0 & 1 & 0 \\
\hline Peritonitis & 0 & 0 & 0 & 0 & 0 & 0 & 0 & 0 & 0 & 0 & 1 & 0 \\
\hline Pneumonia & 3 & 14 & 20 & 18 & 18 & 11 & 30 & 15 & 5 & 11 & 12 & 7 \\
\hline Septicemia & 0 & 3 & 1 & 5 & 5 & 0 & 0 & 0 & 0 & 0 & 0 & 0 \\
\hline Sheep pox & 0 & 0 & 0 & 0 & 0 & 7 & 4 & 0 & 0 & 0 & 0 & 0 \\
\hline UB Rupture & 1 & 0 & 0 & 0 & 0 & 0 & 0 & 0 & 0 & 0 & 0 & 0 \\
\hline Wild attack & 0 & 0 & 0 & 4 & 9 & 10 & 11 & 1 & 3 & 3 & 6 & 0 \\
\hline & 44 & 55 & 104 & 142 & 105 & 89 & 76 & 39 & 27 & 46 & 63 & 33 \\
\hline \multirow[t]{2}{*}{ Season } & \multicolumn{3}{|c|}{ Winter } & \multicolumn{3}{|c|}{ Spring } & \multicolumn{3}{|c|}{ Summer } & \multicolumn{3}{|c|}{ Autumn } \\
\hline & \multicolumn{3}{|c|}{$203(24.67 \%)$} & \multicolumn{3}{|c|}{$336(40.83 \%)$} & \multicolumn{3}{|c|}{$142(17.23 \%)$} & \multicolumn{3}{|c|}{$142(17.23)$} \\
\hline
\end{tabular}


Table.4 Effect of age of animal on mortality in Kashmir Merino sheep due to various infectious and non-infectious diseases during 2013 -20

\begin{tabular}{|c|c|c|c|c|c|}
\hline Disease & 0-30 days & $>1$ to 6 months & $>6-12$ months & $>12-2$ years & $>2$ years \\
\hline Abomasitis & 0 & 3 & 0 & 0 & 0 \\
\hline Aortic Rupture & 0 & 3 & 0 & 0 & 0 \\
\hline Ascites & 0 & 0 & 1 & 0 & 0 \\
\hline Bloat & 2 & 2 & 1 & 1 & 0 \\
\hline Coccidiosis & 0 & 1 & 0 & 0 & 0 \\
\hline Drowning & 0 & 1 & 0 & 0 & 1 \\
\hline Ecthyma & 2 & 3 & 0 & 0 & 0 \\
\hline Encephalitis & 0 & 0 & 1 & 0 & 0 \\
\hline Enteritis & 2 & 24 & 4 & 0 & 1 \\
\hline Enterotoxaemia & 0 & 2 & 0 & 0 & 0 \\
\hline Poisoning & 0 & 1 & 0 & 0 & 2 \\
\hline Fluke Infestation & 0 & 0 & 0 & 0 & 1 \\
\hline Gastritis & 0 & 1 & 0 & 0 & 0 \\
\hline Gastro enteritis & 20 & 54 & 34 & 9 & 42 \\
\hline Gid & 0 & 0 & 48 & 21 & 1 \\
\hline Hemorrhagic enteritis & 8 & 49 & 10 & 1 & 10 \\
\hline Hemorrhagic gastro enteritis & 7 & 20 & 4 & 1 & 6 \\
\hline Hepatitis & 1 & 0 & 0 & 0 & 1 \\
\hline Hydatidosis & 0 & 0 & 0 & 0 & 2 \\
\hline Hypothermia & 44 & 62 & 2 & 0 & 0 \\
\hline Liver abscess & 0 & 0 & 0 & 0 & 12 \\
\hline Liver cirrhosis & 1 & 2 & 2 & 0 & 21 \\
\hline Lung abscess & 1 & 0 & 0 & 1 & 16 \\
\hline Metritis & 0 & 0 & 0 & 0 & 1 \\
\hline Nephrites & 0 & 1 & 0 & 1 & 8 \\
\hline Omasal impaction & 0 & 0 & 0 & 1 & 0 \\
\hline Peritonitis & 0 & 0 & 1 & 0 & 0 \\
\hline Pneumonia & 24 & 81 & 22 & 17 & 20 \\
\hline Septicemia & 1 & 8 & 0 & 0 & 5 \\
\hline Sheep pox & 0 & 11 & 0 & 0 & 0 \\
\hline UB Rupture & 0 & 0 & 1 & 0 & 0 \\
\hline Wild attack & 1 & 21 & 2 & 5 & 18 \\
\hline \%age-1 & $\begin{array}{l}13.89 \\
(114)\end{array}$ & $\begin{array}{l}42.50 \\
(350)\end{array}$ & $\begin{array}{l}16.16 \\
(133)\end{array}$ & $\begin{array}{l}7.05 \\
(58)\end{array}$ & $\begin{array}{l}20.40 \\
(168)\end{array}$ \\
\hline
\end{tabular}

Diseases such as enteritis and pneumonia spread at an alarming rate in highly dense herd. So new born should be shifted to noninfectious environment and also disinfection of sheds should be carried out regularly. Regular vaccination should be carried out to prevent outbreak of any disease. Economics of sheep farm is directly related to the number of the lambs born and their survival to produce adult stock. Thus it is very essential to identify the cause of lamb mortality and take necessary steps to prevent it.

Mortality \% of $13.89,42.50,16.16,9.96,7.05$ and 20.40was observed in age groups of 030days, 30 days-6 months, >6-12, >12 months-2 years and $>2$ years, respectively. Highest mortality percentage was observed 
between first and fifth month of birth while 0 30 day contributed $13.49 \%$ (Table 4). Mendel et al., (1989) reported perinatal mortality of $18.4 \%$ in Merino Landschaf breed and $26.0 \%$ and Bergschaf breed. The cold and contaminated water supply could be predisposing factor in other age groups and in particular mortality during pregnancy and stressful conditions also. The lung and liver abscesses, Liver cirrhosis and Hydatidosis were more common in adult animals.

Maru et al., (1993) also reported lung abscesses a more common cause of deaths in adults. Predation of sheep was by wild animals (mainly bear). Its higher incidence in summer can be was common cause of mortality at high land pastures. The mortality rate in suckling lambs (1-6 months) was higher than other groups suggesting higher vulnerability to death of this age group. The important causes of mortality in this age group were Pneumonia, Hypothermia and Enteritis. The result was in consonance with findings of Maru et al., (1993) and Makhdoomi and Tufani (2010) in sheep. Gid was important cause of mortality in age 6-24 months age groups.

While it is not possible to save every single lamb, but there is huge scope to reduce mortality percentage for economic sheep production. The mortality (\%) was higher among males than females. Deaths in young sheep were significantly higher than older age groups. Significantly higher mortality was observed due to management-responsive factors (wild attacks, hypothermia etc.,), vaccine preventable diseases (Sheep pox etc.,) and diseases with complex etiologies and interacting factors (pneumonia, gastroenteritis etc,). The precipitating factors (i.e. inadequate transfer of maternal immunity through colostrums, poor management system, extreme birth weight, mis-mothering and supply ice cold and contaminated drinking water supply for lamb and ewes during pregnancy and winter seasons) were observed at the farm. The major and pivotal precipitating factor responsible for huge mortality was inadequate grazing time provided to sheep during spring, summer and autumn seasons and ice cold and contaminated drinking water supply during winter and spring seasons.

The highly qualified, disinterested and inexperienced shepherding staff was not allowing sheep adequate grazing hours of 12 to 14 hours. Therefore, it is recommended to provide clean water supply to sheep during winter along with change in policy for appointment of shepherding staff. Outsource shepherding staff (rearing staff) of sheep on contract and engaging only professional folk like Chopans and Gujars engaged in livestock rearing from times immemorial. The sheep should be provided 12-14 hours grazing time for proper growth and body development. The medicines and vaccines for sheep breeding farms should be purchased from reputed pharmaceutical companies.

Also, timely sanction for auction of animals suffering from incurable diseases such as Gid (8.51\%), lung abscess (2.19\%), hydatidosis $(0.24 \%)$ etc. should be done as early as possible. This will significantly reduce the mortality rate at the farm as these incurable diseases contribute $15-20 \%$ of total mortality rate. Adopting these few recommendations along with timely dosing and vaccination will reduce mortality significantly.

\section{References}

Abo-Shehada, M. N., Jebreen, E., Arab, B. 2002. Prevalence of Taenia multiceps in sheep in northern Jordan. Prev Vet Med 55: 201-207.

Gicik Y, Kara M, Arslan M. 2007. Prevalence of Coenurus cerebralis in sheep in Kars 
province. Bull Vet Inst Pulawy; 51: 379382.

Makhdoomi, D. M. and Tufani, N. A. (2010). Infectious and non-infectious diseases as cause of mortality in sheep. Eg. J. Sh. \& G. Sc., Vol.5 (1), P: 349-356.

Mandal, A., Prasad, H., Kumar, A., Roy, R. and Sharma, N. 2007. Factors associated with lamb mortalities in Muzaffarnagari sheep. Small Ruminant Research 71: 273-279.

Maru, A., Srivastava, C. P., Dubey, S. C., \&Lonkar, P. S. (1993). Disease profile of a sheep flock in semi-arid India, Preventive Veterinary Medicine, 15 (1993) $1-17$.

Mendel, C., W. Scholaut, F. Pirchner (1989). Performance of Merinolandschaf and Bergschaf under an accelerated lambing system. Livest. Prod. Sci. 21, 131-141.

Mukasa-Mugerwa, E., Lahlou-Kassi, A., Anindo, D., Rege, J.E.O., Tembely, S., Tibbo, M. and Baker, R.L. 2000. Between and within breed variation in lamb survival and the risk factors associated with major causes of mortality in indigenous Horro and Menz sheep in Ethiopia. Small Ruminant Research 37: 1-12.

Reddy, D. V. V., Sreenivas, D., Gnanaprakash, M., and Harikrishna, C. (2017). Effect of Non-Genetic Factors on Reproductive Performance of Nellore Brown Sheep, 6(3), 896-900.

Sarkar, T.K., Banik, S., Ganai, T.A.S., Singh, P.K. and Ganai, N. 2008. Mortality pattern in exotic and crossbred sheep at an organized farm of Kashmir valley. Indian Journal of Small Ruminants 14: 218-223.

Sawalha, R.M., Conington, J., Brotherstone, S. and Villanueva, B. 2007. Analysis of lamb survival of Scottish Blackface sheep. Animal 1: 151-157.

Tavassoli, M., Malekifard, F., Soleimanzadeh, A., and Tajik, H. (2011). Prevalence of Coenuruscerebralis in sheep in Northwest of Iran, 2(4), 274-276.

Vatankhah, M. and Talebi, M.A. 2009. Genetic and non-genetic factors affecting mortality in Lori-Bakhtiari lambs. Asian-Australasian Journal of Animal Sciences 22: 459-464.

\section{How to cite this article:}

Imran Bashir, Mubashir Ali Rather, Jan Mohammad Rather, Ishfaq Ahmad Hajam, Javaid Ahmad Baba, Mohammad Maroof Shah and Zahoor Ul Haq. 2020. Study of Mortality Pattern in an Organized Farming Sector amongst Kashmir Merino Sheep. Int.J.Curr.Microbiol.App.Sci. 9(04): 1570-1578. doi: https://doi.org/10.20546/ijcmas.2020.904.184 